\title{
Determinants of school bullies: traits and behavior patterns
}

\begin{abstract}
The phenomenon of bullying has been associated with serious mental health problems for both victims and perpetrators of bullying. Western literature is replete with studies that have painted a fair picture of individual and contextual correlates of bullying. Research in India is yet to explore the dynamics of bullying, its correlates and impact. This paper presents the individual level determinants of school bullying among a sample of 40 children 8-11years drawn from two schools of Delhi, India. Overall the results of this study showed that out of a total sample of 20 only one girl was identified as a bully. School bullying was highest among VI grade students. Verbal form of bullying was highest compared to only physical or both these forms of bullying used together. $T$ test revealed that mean sten scores of school bullies were found statistically higher than control group on factors Extraversion \& Independence. The school bullies scored high on extraversion, emotional stability, concrete thinking, warmth, liveliness, rule consciousness, social boldness, sensitivity and self control. Significant differences were found on Children's Apperception test-Human figure, themes of neglect and ignorant, punishing parents. Environment was perceived as depriving, hostile and negligent. School bullies were significantly high on need for autonomy and succorance. Their dominant anxieties of loss of love, blame and punishment and conflicts were $\mathrm{n}$ succorance $\mathrm{v} / \mathrm{s} \mathrm{n}$ rejection, autonomy $\mathrm{v} / \mathrm{s} \mathrm{n}$ abasement, $\mathrm{n}$ autonomy $\mathrm{v} / \mathrm{s}$ punishment which were significantly different from control group. Conclusively, a combination of both personality factors and transaction with parents at home are associated with risk factors for bullying behavior. Intervention programs aimed at reducing bullying should move their focus to helping the child cope with his emotional difficulties and also to intervene to change parent child interaction.
\end{abstract}

Keywords: bullying, bully
Volume 7 Issue $6-2017$

\author{
Paakhi Srivastava, Kanika Sehgal,Tej Bahadur \\ Singh \\ Center for Allied Psychiatry and Psychological Services, USA
}

Correspondence: Paakhi Srivastava, Center for Allied Psychiatry and Psychological Services Pottstown, PA, USA Email paakhisrivastava@gmail.com

Received: May 13, 2017 | Published: June 09, 2017

\section{Introduction}

Bullying has been a part of schooling for as long as children have been congregating. Prevalence studies of past two decades have shown how the incidences of bullying are increasing. The estimated rates of bullying and victimization range from $9 \%$ to $56 \%$ in Australia, ${ }^{1}$ Canada, ${ }^{2}$ Africa, ${ }^{3}$ Germany, ${ }^{4}$ Norway, ${ }^{5,6}$ United States ${ }^{7}$ and India. ${ }^{8}$ Bullying is defined as a repeated aggression in which one or more persons intend to harm or disturb another person physically, verbally, or psychologically. ${ }^{1-9}$ Bullying among children and adolescents affects well-being and psychosocial functioning of both perpetrators and victims. ${ }^{7}$ Any kind of classroom aggression impedes healthy development of children. Impact of bullying increases the risk for delinquency, crime, and alcohol abuse among perpetrators. ${ }^{5-7}$ Haynie et al. (2001) Bullying as a maladaptive behavior leads to immediate gratification in social situations, interfering in acquisition of negiciation and other social skills. Victims on the other hand are at increased risk for depression, anxiety and low self esteem that persist in adulthood. ${ }^{6}$

\section{Research on bullying: the indian scenario}

There is enough literature support from Western studies on individual level and contextual determinants of bullying. However, research on bullying in India is not very old. Though, fighting among students in classrooms and ragging in Indian schools have been common phenomenon since long, but they were recognized as instances of ragging. A differentiation between ragging, and bullying was noticed when instances of school shootouts and peer victimization were reported in news ${ }^{10}$ and reported instances of bullying inflated thereafter. BRITE research has been the significant large scale study to study the phenomena. Bullying Research Initiative in Training and Education (BRITE) project was done at 12 English-medium schools across Dehradun, Munsoorie and Chandigarh consulted nearly 1,200 students and 600 teachers between 2002 and 2005 showed that students have been dealing with bullying not only on the playground, but inside classrooms. The BRITE study shows that 58.7 per cent boys in the age group of 14 to 18 felt that bullying was present on campus, while the figure was higher among girls, 65.09 per cent. ${ }^{11}$ A recent study by Kshirsagar et al., ${ }^{8}$ showed that bullying was reported by 157 (31.4\%) of the 500 children interviewed. ${ }^{8}$ They found no gender differences in prevalence of bullying in coeducation schools. Teasing and keeping names were the commonest forms noticed. Causing physical hurt was reported by $25(16 \%)$ students. Only $24(24 \%)$ parents were aware that their children were being bullied. ${ }^{8}$ There are significant differences reported in forms of bullying with respect to day school or boarding schools. In a day school, it's more of an individual or gang-related phenomenon either a powerful individual attracts the support of a gang of admirers who then proceed to prey upon the weaker ones, or there is a proliferation of gangs who fight each other over different issues (in a co-ed school, for instance, mainly over the attention of girls). However, in boarding schools the victimization is more intentionally physically hurting, verbally abusive, psychologically excruciating and nerve-racking. In Indian studies the consequences of bullying are reported to be; sadness, and preference for staying alone. Bullied children were more likely to report symptoms such as school phobia, vomiting and sleep disturbances. ${ }^{8}$ Those who bully are described to have personalities that are authoritarian with an urge to control or dominate others. Envy and resentment are known motives for bullying. ${ }^{10}$ So far, there are a handful of systematic studies in India exploring the phenomena of 
bullying. Considering that bullying as a problem is on rise, any planned intervention would rest on culturally relevant knowledge about causal relationship between individual, contextual and group processes. However, conclusions about determinants of school bullies are largely derived from Western literature. The present study is aimed at studying the individual characteristics of school bullies. Identification of early individual factors of school bullies may guide the prevention strategies for managing bullying behaviors. Early identification provides scope to change the trajectory of children at risk for mental health problems, independent of school and neighborhood factors.

\section{Methods}

The study was conducted among IV to VII grade students drawn from two schools from North and East Delhi. Five schools were approached for the study out of which three gave consent for participation and two schools were selected using purposive sampling to include a government and a private school so as to make data representative. Government school consisted $87 \%$ of children coming from low socioeconomic status. And private school comprised of $73 \%$ middle socioeconomic status and 19\% from high socioeconomic status. The study does not include students in special education, convent school and gifted-student programs. Participation information was provided and the written consent was obtained from the school authorities. Parental consent was obtained. Students provided assent. As part of the assent procedure, students were assured confidentiality. The final sample consisted of total 40 participants, 20 school bullies (19 boys, 1 girl) and 20 control group (19 boys and 1 girl). The five students were selected each from four grades from IV (mean age $=8$ ), $\mathrm{V}$ (mean age=9), VI (mean age=10) \& VII (mean age=11). The subjects were matched on age, gender and grade level.

\section{Measures}

\section{Sociometry}

Sociometry is a quantitative method for measuring social relationships. Research sociometry is action research with groups exploring the socio-emotional networks of relationships using specified criteria.

Identification data sheet: This was a semi structured interview schedule to collect information about the demographic details of the study participants.

Teacher's form: this was a very brief semi-structured interview schedule which gathered information about the type of bullying behavior displayed by the school bullies.

Developemental psychopathology checklist (kapur \& harsave, 2002): It has been developed by Kapur \& Harsave in 2002 to be used for various clinical and research purposes. It is designed to record in a standardized format, the psychological problems and competencies of children as reported by parent and/or teacher. The checklist of 124 items assessing six basic dimensions including developmental history, developmental problems, psychopathology (hyperkinesis, conduct disorders, learning problems, emotional disorders, obsessive compulsive disorders, somatic problems, hysteria and psychosis), psychosocial stressors, temperamental profile and supportive factors. It can be used across age groups, gender both cross-sectionally and longitudinally and is simplied to suit Indian context.

Children's personality questionnaire (Porter \& Ctatell, 1979): The Children's Personality Questionnaire (CPQ) is a standardized personality measure for children ages 8-12. The questionnaire targets 14 dimensions of personality taken from a factor analysis of personality performed by Cattell in 1950. Each form contains 140 items, ten for each dimension. It reveals important information about academic achievement, leadership potential, and the tendency toward disciplinary problems. The CPQ report also provides narrative interpretations relative to traits such as creativity, emotional stability, self-concept level, excitability, and apprehension, as well as derived scores and predictions for extraversion, anxiety, and other broad trait patterns. Test-retest reliability after a one- week interval for each of the 14 factors on the various test forms ranges from .28-.87. The Kuder-Richardson Formula 21 shows internal consistencies ranging from .32-.86.

\section{Procedure}

The research was carried out in two phases: Screening Phase and Assessment Phase. Screening phase began with discussions with the class teachers of all the sections of grades IV to VII in a group sensitizing them about bullying and associated processes. Verbal consent was obtained from them for their participation and cooperation. The interaction with students was made once a week, for one hour each during the free periods, substitutions, or rarely games period. Researcher (author) familiarized the students to concept of bullying. Information thus elicited was used to develop an instruction for the purpose of identification of school bullies.

Sociometry technique was explained following which peer and class teacher's nominations were taken. Peers and class teacher enlisted 4 students from the class roster who fits the descriptions of a "bully" (repeatedly over time and/or on several occasions hits, teases, snatches, starts fighting, spreads rumors, excludes from group and appears stronger than you). The description was presented through audio and visual mode in Hindi. To identify a bully, a standardized percent nomination (SPN) was calculated. SPN was obtained by summing up frequencies of nomination gained by each student divided by total number of students. 0.8 was considered as cut off based on review of literature; suggesting a student getting an SPN of 0.8 is considered a bully by almost $80 \%$ of the students. ${ }^{12} \mathrm{~A}$ total of five to seven nominations were received from each grade, a total of 44 students were identified as school bullies. Kapur \& Harisave (2002) 40 students were selected as control group from the same grades randomly. The parents of these students as well as control group were called to school to obtain informed consent and also to screen these students for mental health problems using Developmental Psychopathology Checklist. Similar procedure was done for control group. After screening on DPCL, 32 students were left who had no mental health problem. Out of this group of school bullies, those students were selected in equal number from all the four grades who scored highest percentage of votes in the order of hierarchy on sociometry. 20 school bullies were thus identified. In control group, 28 students were identified with absence of mental health problem. Data collection was completed over 56 biweekly visits to the school. Individual administration of Children's personality questionnaire (CPQ). Teachers filled a form about the details of the type of bullying behavior the school bullies engaged in.

\section{Statistical analysis}

Scoring for each protocol was done as per instructions for each tool used. The demographic details of the data were analyzed and discussed using descriptive statistics including mean and standard deviation. To compare the personality profile of school bullies and those of control group using CPQ, the mean of sten scores were 
calculated as per instructions given in manual. The mean sten scores of both the groups were compared using $t$ test. The profile of the personality characteristics of school bullies was depicted graphically. To compare the personality and its psychic structure using CAT-H, the scoring was done using the Bellack \& Bellack scoring system. Subsequently, frequencies and percentages (Descriptive statistics) was calculated for each of the category of characteristics including themes, needs, conflicts, defense mechanisms. For all statistical procedures, SPSS version 11.0 was used.

\section{Results}

\section{Demographic characteristics of perpetrators of bullying}

The demographic details have been presented in Table 1. The mean age of perpetrators of bullying was $9.50+/-1.14$.

Table I Demographic details of the sample

\begin{tabular}{|c|c|c|c|c|}
\hline \multirow[t]{2}{*}{ Variables } & \multicolumn{2}{|c|}{ School Bullies $(\mathbf{N}=20)$} & \multicolumn{2}{|c|}{ Control Group $(\mathrm{N}=\mathbf{2 0})$} \\
\hline & Mean & S.D & Mean & S.D \\
\hline Age & 9.5 & $\mathrm{I} .147$ & 9.45 & 1.398 \\
\hline
\end{tabular}

Table below illustrates the mean and standard deviation of the age of the study participants including 20 school bullies and 20 normal group.

\section{Results of sociometry}

The percentage of votes received by perpetrators range from $16.47 \%$ to $40.22 \%$. The range of percentage is wider in grades VI and VII indicating that there may be one or two bullies who are more disruptive and repetitive in their bullying behavior compared to those in lower grades. Boys were more likely to engage in bullying compared to girls $(19 \mathrm{v} / \mathrm{s} 1) .40 \%$ of school bullies engage in verbal forms of bullying as compared to $30 \%$ engaging in only verbal bullying, and $30 \%$ engage in both the forms of bullying (Table $2 \& 3$ ).

Table 2 Percentage of votes obtained by each school bully by the class mates and teacher

\begin{tabular}{lll}
\hline Serial Number & Grade & Percentage of Votes \\
\hline I & IV & $25.51 \%$ \\
2 & IV & $25 \%$ \\
3 & IV & $21.34 \%$ \\
4 & IV & $20.40 \%$ \\
5 & IV & $19.10 \%$ \\
6 & V & $33.33 \%$ \\
7 & V & $30.30 \%$ \\
8 & V & $27.27 \%$ \\
9 & V & $26.04 \%$ \\
10 & V & $16.47 \%$ \\
11 & VI & $40.22 \%$ \\
12 & VI & $35.71 \%$ \\
13 & VI & $31 \%$ \\
14 & VI & $26.92 \%$ \\
15 & VI & $19.23 \%$ \\
16 & VII & $34 \%$ \\
17 & VII & $29.41 \%$ \\
18 & VII & $22.98 \%$ \\
19 & VII & $17.89 \%$ \\
20 & VII & $16.66 \%$ \\
\hline
\end{tabular}

Table 3 Types of bullying behavior demonstrated by school bullies

\begin{tabular}{lll}
\hline Type of Bullying Behavior & School Bullies \\
\hline & Frequency & Percentage \\
\hline Physical & 6 & $30 \%$ \\
Verbal & 8 & $40 \%$ \\
Both & 6 & $30 \%$ \\
\hline
\end{tabular}

Table below illustrates that $40 \%$ of school bullies engage in verbal forms of bullying as compared to $30 \%$ engaging in only verbal bullying, and $30 \%$ engage in both the forms of bullying

\section{Individual characteristics of perpetrators of bullying}

Children's personality questionnaire: The comparison of mean sten scores on CPQ obtained by perpetrators of bullying and control group is shown in Table 4. Mean of school bullies were found significantly high on Extraversion (socially participative) \& Independence (independent, persuasive and willfull) as compared to control group. However, school bullies had lower mean scores on Tough poise (Open-Minded and Intuitive) than control group. Mean scores of school bullies relative to control group were also significantly higher on factors Warmth, Reasoning, Emotional Stability, Liveliness, Rule consciousness, Social Boldness, Sensitivity and Self Control. The primary personal characteristics of significance for perpetrators of bully included Concrete Thinking (Mean Sten Factor B=3.15), Pheligmatic Temperament (Mean Sten Factor $D=2.40$ ), Conforming (Mean Sten Factor E= 3.55), Artless (Mean Sten Factor N=3.45) and Untroubled Adequacy (Mean Sten $\mathrm{O}=3.15)($ Graph 1).

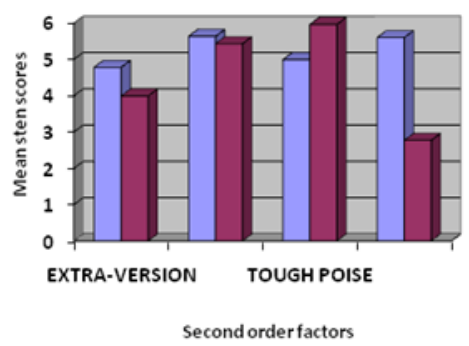

口SCHOOLBULUES aCONTROL

Graph I Comparison of mean scores of two groups on second order factors of Children's Personality Questionnaire.

Graph above illustrates the mean scores obtained by school bullies and control group on second order factors of CPQ. Results show that there is significant difference between factors Extraversion and Independence at $\mathrm{P}$ value $0.01 \& 0.05$

\section{Dynamic structure of behavior pattern}

Themes: Significant differences were seen on thematic structure of stories on cards III, V, VII, VIII, IX and X (Table 5). Compared to $60 \%$ of control group, $75 \%$ of perpetrators had theme of powerful adult oppressing a child. On card V, the theme of parental neglect was dominant in $80 \%$ of stories by perpetrators however none on control group constructed stories around this theme. $75 \%$ bullies contrasting to $40 \%$ of controls had perceived hero being abandoned and punished for his mischief on card V. On card VI,VII and VIII are replete with themes of hero tests his own potentials as an independent unit, such explorations were limited by environmental limitations, punishment by authority figures, lack of sympathetic guidance. Of relevance are constructions on card VI where $75 \%$ of the school bullies in comparison to $20 \%$ of controls made story around theme of children exploring and exercising autonomy by going for camping alone. However, the hero gets lost, is attacked by animals with no adult to rescue him. On card 
VII $50 \%$ school bullies compared to $40 \%$ of controls reported themes of hero being punished, humiliated and attacked with no adult saving them. On card VIII, $80 \%$ of perpetrators in contrast to none of controls perceived parents as insulting child in front of their friends. On card IX most common theme ( $85 \%$ bullies $\mathrm{v} / \mathrm{s} 70 \%$ controls) was that of child being left alone by parents as a part of his punishment. On card $\mathrm{X}$, the common them included, child being uncared for by parents, and deliberations to tease the adult. Conclusively these themes reflect that school bullies perceive their environment as more depriving, lacking in support, punishing and indifferent to their need for affection (Tables 6-8).

Table 4 Comparison of mean and S.D. between two groups on children's personality questionnaire

\begin{tabular}{|c|c|c|c|c|c|}
\hline \multirow[t]{2}{*}{ Factor } & \multicolumn{2}{|c|}{ School Bullies } & \multicolumn{2}{|c|}{$\begin{array}{l}\text { Normal } \\
\text { Participants }\end{array}$} & \multirow[t]{2}{*}{ t ratio } \\
\hline & Mean & S.D & Mean & S.D & \\
\hline Extraversion & 4.78 & 0.577 & 3.99 & 0.445 & $7.947^{* *}$ \\
\hline Anxiety & 5.63 & 0.568 & 5.43 & 0.271 & 6.091 \\
\hline Tough poise & 4.99 & 0.847 & 5.96 & 0.518 & $4.108 * *$ \\
\hline Independence & 5.6 & 0.737 & 2.77 & 0.436 & $7.812 * *$ \\
\hline Factor A & 6.55 & 1.731 & 3.75 & 1.02 & $6.760 * *$ \\
\hline Factor B & 3.15 & 0.988 & 1.85 & 1.04 & $3.650 * *$ \\
\hline Factor C & 6.45 & I.791 & 2.8 & 0.951 & $7.648 * *$ \\
\hline Factor D & 2.4 & 1.501 & 2.4 & 0.681 & 0 \\
\hline Factor E & 3.55 & 1.669 & 3.2 & 1.508 & $.66 I^{*}$ \\
\hline Factor F & 4.75 & 1.65 & 2.6 & 1.188 & $4.505 * *$ \\
\hline Factor G & 6.35 & 1.461 & 3.6 & 0.995 & $6.935 * *$ \\
\hline Factor $\mathrm{H}$ & 6.3 & 1.418 & 2.5 & I.147 & $9.174 * *$ \\
\hline Factor I & 6.05 & 1.395 & 3.25 & 1.164 & $6.380 * *$ \\
\hline Factor J & 4.95 & 1.701 & 3.65 & 1.268 & $2.668^{*}$ \\
\hline Factor $\mathrm{N}$ & 3.45 & 1.099 & 2.1 & $\mathrm{I} .447$ & $3.857^{* *}$ \\
\hline Factor $O$ & 3.15 & 1.496 & 2.6 & 1.046 & $1.124 *$ \\
\hline Factor Q3 & 6.7 & 1.867 & 3 & 1.414 & $6.934 * *$ \\
\hline Factor Q4 & 3.9 & 2.125 & 3.6 & 1.188 & 0.603 \\
\hline
\end{tabular}

Table below illustrates the mean and standard deviations of the scores obtained by school bullies and control group. Mean of school bullies were found significantly high on Extraversion \& Independence as compared to control group at $p$ value $0.01 \& 0.05$. However, school bullies had lower mean scores on Tough poise than control group which is significant at $p=0.01$ Mean scores of school bullies were also significantly higher on factors $A, B, C, F, G, H, I, N \& Q 3$ at both the 0.01 \& 0.05 levels of significance. However, school bullies scored significantly high on E, J \& $O$. There was no statistically significant difference on factors $D$ \& $Q 4$ *significant at 0.05 , **significant at 0.01 level

Table 5 Comparison of two groups on themes on children's apperception test

\begin{tabular}{lllll}
\hline \multirow{2}{*}{ Themes } & \multicolumn{2}{l}{ School Bullies } & \multicolumn{2}{l}{ Control Group } \\
\cline { 2 - 5 } & Frequency & Percentage & Frequency & Percentage \\
\hline Card I & & & & \\
Punishment & 8 & 40 & 14 & 70 \\
$\begin{array}{l}\text { Neglect } \\
\text { Card II }\end{array}$ & 0 & & 6 & 30 \\
$\begin{array}{l}\text { Competitive } \\
\text { game }\end{array}$ & 11 & 55 & 14 & 70 \\
Fight & 9 & 45 & 6 & 30 \\
Card III & & & & \\
Powerful adult & 15 & 75 & 8 & 40 \\
Child teases & 5 & 25 & 12 & 60 \\
Card IV & & & & \\
Picnic & 2 & 10 & 6 & 30 \\
\hline
\end{tabular}

Table Continued...

\begin{tabular}{|c|c|c|c|c|}
\hline \multirow[t]{2}{*}{ Themes } & \multicolumn{2}{|c|}{ School Bullies } & \multicolumn{2}{|c|}{ Control Group } \\
\hline & Frequency & Percentage & Frequency & Percentage \\
\hline $\begin{array}{l}\text { Sibling rivalry / } \\
\text { Neglect }\end{array}$ & $0-16$ & $0-80$ & $14-00$ & 70 \\
\hline \multicolumn{5}{|l|}{ CardV } \\
\hline Primal scene & 0 & & 12 & 60 \\
\hline Child naughty & 15 & 75 & 8 & 40 \\
\hline Child deprived & 5 & 25 & & \\
\hline \multicolumn{5}{|l|}{ CardVI } \\
\hline Child attacked & 5 & 25 & 16 & 80 \\
\hline Child deprived & 15 & 75 & 4 & 20 \\
\hline \multicolumn{5}{|l|}{ Card VII } \\
\hline \multirow[t]{2}{*}{$\begin{array}{l}\text { Child attacked } \\
\text { Retaliates }\end{array}$} & 10 & 50 & 8 & 40 \\
\hline & 5 & 25 & 12 & 60 \\
\hline \multicolumn{5}{|l|}{ Card VIII } \\
\hline Parent scolding & 2 & 10 & 16 & 80 \\
\hline Child helpful & 2 & 10 & 4 & 20 \\
\hline Parent ignoring & 16 & 80 & & \\
\hline \multicolumn{5}{|l|}{ Card IX } \\
\hline Fear of attack & 3 & 15 & 6 & 30 \\
\hline Loneliness & 17 & 85 & 14 & 70 \\
\hline \multicolumn{5}{|l|}{ Card X } \\
\hline $\begin{array}{l}\text { Toilet } \\
\text { naughtiness }\end{array}$ & 5 & 25 & 14 & 70 \\
\hline $\begin{array}{l}\text { Punishing } \\
\text { parents }\end{array}$ & 15 & 75 & 6 & 30 \\
\hline
\end{tabular}

Table below illustrates the number and percentage of school bullies and control group on themes of CAT. $85 \%$ of school bullies as compared to $70 \%$ control group had themes of loneliness on Card IX, while $80 \%$ of school bullies constructed stories with the theme of neglect on card IV and ignorant parent on Card VIII compared to $70 \%$ \& $0 \%$ respectively by control group. $75 \%$ school bullies constructed stories with themes of naughty child on Card V, deprived child on Card VI, and punishing parents compared to 40\%, 20\%, 30\% respectively of control group.

Table 6 Comparison of attributes of hero, interpretation of figures, press, perceived by two groups on children's apperception test

\begin{tabular}{|c|c|c|c|c|c|}
\hline & & School Bu & & Control G & \\
\hline A. & Hero & Frequency & Percentage & Frequency & Percentag \\
\hline 1 & Main & 18 & 90 & 12 & 60 \\
\hline 2 & Partial & 2 & 10 & 8 & 40 \\
\hline B. & Press & & & & \\
\hline 1 & Hostile/Lacking & 16 & 80 & 8 & 40 \\
\hline 2 & Congenial & 4 & 20 & 12 & 60 \\
\hline c. & Perception of Figure & & & & \\
\hline 1 & Hostile & 4 & 20 & 2 & 10 \\
\hline 2 & Negligent & 12 & 60 & 2 & 10 \\
\hline 3 & Nurturing & 4 & 20 & 16 & 80 \\
\hline D. & Nature of anxiety & & & & \\
\hline 1 & Orality & 3 & 15 & 8 & 40 \\
\hline 2 & $\begin{array}{l}\text { Parental } \\
\text { Threat }\end{array}$ & 4 & 20 & 4 & 20 \\
\hline 3 & Loss of love & 7 & 35 & 2 & 10 \\
\hline 4 & Punishment & 2 & 10 & 2 & 10 \\
\hline 5 & Blame & 4 & 20 & 4 & 20 \\
\hline E. & Superego & & & & \\
\hline 1 & Adequate & 12 & 60 & 12 & 60 \\
\hline 2 & Inadequate & 8 & 40 & 8 & 40 \\
\hline F. & Defenses & & & & \\
\hline
\end{tabular}


Table Continued...

\begin{tabular}{llllll}
\hline & & \multicolumn{2}{c}{ School Bullies } & \multicolumn{2}{c}{ Control Group } \\
\hline I & $\begin{array}{l}\text { Reaction } \\
\text { Formation }\end{array}$ & 4 & 20 & 10 & 50 \\
2 & Regression & 6 & 30 & 0 & 0 \\
3 & Projection & 8 & 40 & 6 & 30 \\
4 & Deception & 1 & 5 & 2 & 10 \\
5 & Intellectualization & 1 & 5 & 2 & 10 \\
G. & Interpretation of Hero & & & \\
I & Meek & 12 & 60 & 6 & 30 \\
2 & Strong & 8 & 40 & 14 & 70 \\
H. & Outcome & & & & \\
I & Positive & 11 & 55 & 14 & 70 \\
2 & Negative & 9 & 45 & 6 & 30 \\
\hline
\end{tabular}

Table below illustrates the number and percentage of school bullies and control group on attributes of hero, perception of figure and environment. While $80 \%$ of school bullies as compared to $40 \%$ of control group find the environment as lacking /hostile. $60 \%$ compared to 10\% control group of school bullies found the figures as negligent. $35 \%$ of school bullies compared to $10 \%$ of control group projected loss of love as dominant anxiety followed by $20 \%$ school bullies with parental threat and blame as dominant anxiety. $60 \%$ of school bullies compared to only $30 \%$ of control group found the hero as meek. $45 \%$ school bullies perceive negative outcomes compared to $30 \%$ of control group

Table 7 Comparison of needs of hero perceived by two groups on children's apperception test

\begin{tabular}{|c|c|c|c|c|c|}
\hline \multirow{2}{*}{$\begin{array}{l}\text { S. } \\
\text { No }\end{array}$} & \multirow[t]{2}{*}{ Needs } & \multicolumn{2}{|c|}{ School Bullies } & \multicolumn{2}{|c|}{ Control Group } \\
\hline & & Frequency & Percentage & Frequency & Percentage \\
\hline 1 & Abasement & 18 & 90 & 12 & 60 \\
\hline 2 & Achievement & 12 & 60 & 12 & 60 \\
\hline 3 & Acquisition & 4 & 20 & 8 & 40 \\
\hline 4 & Affiliation & 6 & 30 & 6 & 30 \\
\hline 5 & Aggression & 17 & 85 & 2 & 10 \\
\hline 6 & Autonomy & 18 & 90 & 6 & 30 \\
\hline 7 & $\begin{array}{l}\text { Blame } \\
\text { Avoidance }\end{array}$ & 8 & 40 & 2 & 10 \\
\hline 8 & Cognizance & 6 & 30 & 2 & 10 \\
\hline 9 & Counteraction & 10 & 50 & 2 & 10 \\
\hline 10 & Deference & 3 & 15 & 12 & 60 \\
\hline II & Dominance & 9 & 45 & 12 & 60 \\
\hline 12 & Exposition & 1 & 5 & 4 & 20 \\
\hline 13 & $\begin{array}{l}\text { Harm } \\
\text { Avoidance }\end{array}$ & 6 & 30 & 10 & 50 \\
\hline 14 & Intraggression & 4 & 20 & 4 & 20 \\
\hline 15 & Nurturance & 4 & 20 & 14 & 70 \\
\hline 16 & Order & 1 & 5 & 2 & 10 \\
\hline 17 & Passivity & 2 & 10 & 12 & 60 \\
\hline 18 & Recognition & 1 & 5 & 6 & 30 \\
\hline 19 & Rejection & 4 & 20 & 2 & 10 \\
\hline 20 & Sex & 1 & 5 & 10 & 50 \\
\hline 21 & Similance & 2 & 10 & 4 & 20 \\
\hline 23 & Succorance & 14 & 70 & 4 & 20 \\
\hline 24 & Contrience & 1 & 5 & 18 & 90 \\
\hline 25 & Infavoidance & 8 & 40 & 2 & 10 \\
\hline
\end{tabular}

The below table illustrates the number and percentage of needs of school bullies and control group as reported on CAT. $90 \%$ of school bullies as compared to $60 \%$ of control group have need of abasement, $90 \%$ of school also have need for autonomy compared to $30 \%$ of control group. $85 \%$ of school bullies as compared to $10 \%$ of control group have need for aggression and $70 \%$ of school bullies have need for succorance as compared to $20 \%$ of control group
Table 8 Comparison of conflicts of hero perceived by two groups on children's apperception test

\begin{tabular}{|c|c|c|c|c|c|}
\hline \multirow[t]{2}{*}{$\begin{array}{l}\text { S. } \\
\text { No }\end{array}$} & \multirow[t]{2}{*}{ Conflicts } & \multicolumn{2}{|c|}{ School Bullies } & \multicolumn{2}{|c|}{ Control Group } \\
\hline & & Frequency & Percentage & Frequency & Percentage \\
\hline I & $\begin{array}{l}\text { Affiliation v/s } \\
\text { aggression }\end{array}$ & 5 & 25 & 2 & 10 \\
\hline 2 & $\begin{array}{l}\text { Affiliation } v / s \\
\text { rejection }\end{array}$ & 5 & 25 & 2 & 10 \\
\hline 3 & Id v/a Superego & 8 & 40 & 4 & 20 \\
\hline 4 & $\begin{array}{l}\text { Dominance } \mathrm{v} / \mathrm{s} \\
\text { Autonomy }\end{array}$ & 4 & 20 & 2 & 10 \\
\hline 5 & $\begin{array}{l}\text { Nurturance v/s } \\
\text { aggression }\end{array}$ & 1 & 5 & 4 & 20 \\
\hline 6 & $\begin{array}{l}\text { Dominance } \mathrm{v} / \mathrm{s} \\
\text { abasement }\end{array}$ & 3 & 15 & 2 & 10 \\
\hline 7 & $\begin{array}{l}\text { Succorance } \mathrm{v} / \mathrm{s} \\
\text { rejection }\end{array}$ & 13 & 65 & 2 & 10 \\
\hline 8 & $\begin{array}{l}\text { Intraggression } \\
\text { v/s aggression }\end{array}$ & 2 & 10 & 2 & 10 \\
\hline 9 & $\begin{array}{l}\text { Acquisition v/s } \\
\text { rejection }\end{array}$ & 0 & & 4 & 20 \\
\hline 10 & $\begin{array}{l}\text { Aggression v/s } \\
\text { counteraction. }\end{array}$ & 7 & 35 & 2 & 10 \\
\hline II & $\begin{array}{l}\text { Autonomy v/s } \\
\text { affiliation }\end{array}$ & 4 & 20 & 4 & 20 \\
\hline 12 & $\begin{array}{l}\text { Autonomy v/s } \\
\text { punishment }\end{array}$ & 11 & 55 & 2 & 10 \\
\hline 13 & $\begin{array}{l}\text { Autonomy v/s } \\
\text { abasement }\end{array}$ & 13 & 65 & 4 & 20 \\
\hline
\end{tabular}

\section{Attributes of hero, interpretation of figures, press, and outcome}

The number and percentage of school bullies and control group on attributes of hero, perception of figure and environment are displayed in Table $4.90 \%$ of perpetrators compared to only $60 \%$ of controls had complete identification with the same gender and same age character reflecting adequate projection. $80 \%$ of school bullies as compared to $40 \%$ of control group find the environment as lacking in affection and guidance in turn being hostile. $60 \%$ compared to $10 \%$ control group of school bullies found the figures as negligent. $35 \%$ of school bullies compared to $10 \%$ of control group had loss of love and $20 \%$ school bullies had threat from parents and possibility of being blamed as dominant anxiety. The main defense employed by $40 \%$ of perpetrators in contrast with $30 \%$ of controls was found to be projection. Regression (themes of food being spilled, pants wet, urinating or defecating in pants, dirty, messy hero) was identified as dominant defense among $30 \%$ of bullies compared to none in control group. $60 \%$ of school bullies compared to only $30 \%$ of control group found the hero as meek. Only $55 \%$ school bullies perceive positive outcomes compared to $70 \%$ of control group.

Needs: Significantly, $90 \%$ of school bullies as compared to $60 \%$ of control group had need of abasement which was evident in themes of accepting punishment or shame and endurance of neglect without attempts to counteract. $90 \%$ of bullies also had need for autonomy compared to $30 \%$ of control group. Need for autonomy was not confined to a social needs, the dominant content of this need was desire to remain independent, to explore own capacities intermingled with need to defy rules and disobey parents. $85 \%$ of school bullies as compared to $10 \%$ of control group have need for aggression. Aggression needs included need to defend oneself against punishment, aggression against prescribed rules by teachers and parents. $70 \%$ of school bullies have need for succorance as compared 
to $20 \%$ of control group. Desire for attention, affection and guidance are manifest in the stories.

Dominant conflicts: $65 \%$ of school bullies compared to only $10 \%$ of control group projected conflicts of $\mathrm{n}$ succorance $\mathrm{v} / \mathrm{s} \mathrm{n}$ rejection (desire for affection from parents and receding from the same resulting from frustration of needs). $65 \%$ school bullies as compared to control group with had conflicts of autonomy v/s $\mathrm{n}$ abasement (children seeked independence in determining their behavior which often met with physical restraints or mishaps leading to submission to limitations). $55 \%$ of school bullies compared to $10 \%$ of control group showed conflicts between $\mathrm{n}$ autonomy v/s punishment (often autonomous behaviors, going for trips, shopping for self, spending time with friends, taking decisions coerced with punishment including physical assaults and inducing shame).

\section{Discussion}

The present study aimed at exploring the individual characteristics of perpetrators of school bully. Its specific goals were to assess the personality traits of the school bullies and also to assess for the dynamic structure of these personality traits. This study provided a glimpse of individual level determinants of bullying in Indian context. Gender differences were prominent with a single girl identified as bully. Farrington reported that boys bullied more than girls corroborating with the findings of the current study. This difference may be understood in light of gender stereotypes that exist in our culture. Bully image is more incongruent with culturally determined image of a girl in India. Boys engaged in both verbal and physical bullying however, female engaged mostly in verbal bullying and occasionally in physical bullying limited to hitting other girls. The common forms of physical bullying included slapping, pulling hair, poking pen in the body of victims and often punching. Verbal bullying included calling names, social exclusion and only rarely using abusive words. This finding is supported by the recent study by Felix and McMahon who state that males employ physical victimization, harming others through violence; whereas females employ relational victimization, harming others by damaging their relationships (2006:708). On enquiry, it was found that the bully girl was a higher academic achiever holding the position of class monitor. Relevance of contextual factors ${ }^{13}$ was evident as the bully behavior was manifest while a power difference existed. Girl bully would bully other while on duty and on occasions would hit boys. The distribution of votes was spread wider for higher grades indicating that there may be few bullies with more intense, disruptive and engage in repetitive bullying acts than in lower grades. Results in present study suggest that bullies tend to be selective in identifying their targets (bully nominations $<50 \%$ ). The percentage of votes received is higher for grade VI, suggesting that bullying behavior was heightened in this grade compared with other grades. This is supported results of study by Nansel et al., ${ }^{8}$ who found that bullying peaks in the middle school years, with higher percentage coming from grades six through ten. Present research attempted to identify individual risk factors for engaging in bullying behavior. Results on objective measure revealed that bullies are more likely to have a constellation of traits including extraversion, emotional stability, concrete thinking, warmth, liveliness, rule consciousness, social boldness, sensitivity and self control. The findings of present study are in contrast to the other researches which propose that bullies have aggressive personality with rule rejection and failure to cooperate $^{6}$ and marked need to dominate, assert and suppress others. ${ }^{14,15}$ An interesting finding was that school bullies tend to be active, responsive, friendly, yet, impulsive, carefree and can't attend to danger signals. It is consistent with perpetrator's tendency to have difficulty in reading social cues and displaying internally driven behavior patterns in group situations. These findings were corroborated by CAT stories which revealed that school bullies were disturbed by their existing self image, and attempted to control their impulsivity however, they found themselves lacking in skills to materialize the attempts. Research studies report that school bullies lack appropriate self regulation skills. ${ }^{6-17}$ This suggests pathway for intervention with components of impulse control and social skills training. The thematic structure of the perpetrator's stories on CAT-H manifested persistence need for autonomy which is impeded by personal limitations, unfavorable environment and overcontrolling parents. Stories were replete with neglect, harsh punishment and aggression by parental figures. These findings indicate a bidirectional relationship between hostile environments and bullying behavior, however cause and effect could not be established. Early findings by Olweus ${ }^{6}$ suggested that family backgrounds of bullies are characterized by neglect, dominance, hostility, and harsh punishment. Curtner-Smith \& Smith ${ }^{18}$ found that parents who are disagreeable, hostile, cold or rejecting tend to have children who are at risk of becoming aggressive. With the findings on Children's Personality Questionnaire, it can be seen that school bullies do not have aggressive disposition or poor ego strength. It may be concluded that bullying may be behavioral problem or an externalization of emotional problems. Psychoanalysts propose that children who engage in delinquent behavior are essentially those who feel psychologically abandoned by their parents. ${ }^{19}$ Researchers implicate modeling of aggressive behavior at home is as one of the factors in precipitating bullying at school. ${ }^{4-20}$ In the present study, abandonment and punishment by oppressive parents consequent to exercise of autonomy was a dominant theme in CAT-H stories. It appears then from the findings of present study, that, child may have learnt to abuse power at home. This holds enough relevance in our system where the power hierarchies exist in our caste system and parents serve as role models for children who learn to bully servants from a very early age. ${ }^{10}$ As opposed to common practice of stigmatized shaming of a bully or punitive measures, interventions aimed at building positive interpersonal dynamics between child and parents is likely to change the their emotional development with subsequent decline in bullying behavior. ${ }^{4}$ Self perception is poor with more than often resigning to authority after seeming powerlessness. Perpetrators lacked social judgment, had poor frustration tolerance and lack of tolerance and poor self regulation. There was presence of fantasy life, wishful thinking, regression as main defense mechanism. Baumeister et al., ${ }^{21}$ proposed that bullies have unstable ego strength and poor frustration tolerance, they are prone to react defensively to ego threats, and they are also more prone to hostility, anger, and aggression than other people. The results of the present investigation point to the early development of dispositional traits and behavioral patterns among children who bully others. The impact of gender, school factors, interpersonal dynamics and power hierarchies in family interacting with individual factors. Of significance is the possibility for sub-threshold depression among school bullies given emotional difficulties expressed by bullies on projective testing. Maladaptive behavior pattern have roots in frustration of emotional needs, violations of child's autonomy and disposition of poor emotional tolerance. With regard to treatment programs for bullies, these findings have important implications for intervention and early prevention. Individual and group treatment programs may be planned to impart emotional regulation and social skills training for children and programs with parents to establish mutual regulations between child and parent. The present sample is small, and the results should be deemed preliminary. The sample for the study was heterogenous; however, results did not interpret personality dimensions across 
more severe or less severe bullies. Psychopathology associated with bullying behavior could be assessed in future though in present study the bullies with associated psychopathology were excluded. The results of the study could be substantiated if an objective measure to assess family environment and parent child relationship. Another limitation of the study was that possibility of bullies being victims themselves was not assessed and screened out; further research could use this information. In conclusion, bullying is clearly a complex phenomenon. Understanding its multiple causal agents should be an important focus of future work..$^{22-45}$

\section{Acknowledgments}

None.

\section{Conflicts of interest}

Author declares there are no conflicts of interest.

\section{Funding}

None.

\section{References}

1. Rigby K, Slee PT. Australia. In: Smith PK, et al. (Eds.), The Nature of School Bullying: A Cross National Perspective Routledge, UK. 1999. p.324-339.

2. Bidwell PM, Bonett DG. Prevalence rates of peer victimization in Canada. Psychological Bulletin. 1999;88:588-606.

3. Greff LD, Huesmann RL, Dubow E, et al. Childhood aggression and its correlates over 22 years. In: Crowell IM, Evans, \& CRO'Donnell (Eds.), Childhood aggression and violence, Plenum Press, USA. 2004 p.249-262.

4. Ahmed E, Harris N, Braithwaite J, et al, Shame Management Through Reintegration. ( $1^{\text {st }}$ edn), Cambridge University Press, UK. 2001. p.1-390.

5. Olweus D. Aggression in the schools: Bullies and whipping boys. Washington DC: Hemisphere (Wiley). 1978.

6. Olweus D. Bullying at school - What we know and what we can do Blackwell Publishers, USA. 1993.

7. Nansel TR, Overpeck M, Pilla RS, et al. Bullying Behaviors among US youth: Prevelence and association with psychosocial adjustment. Journal of American Medical Association. 2001;285(16):2094-2100.

8. Kshirsagar VY, Agarwal R, Bavdekar SB. Bullying in schools: prevalence and short-term impact. Indian Pediatrics. 2007;44(1):25-28.

9. Olweus D. Bullying at school - Long-term outcomes for the victims and an effective school-based intervention program. In Rowell Huesmann L (Ed.), Aggressive Behaviour: Current Perspectives, Plenum Press, UK. 1994. p.97-130

10. Lahiri D. Bulling in Indian schools. The Times of India. 2006;1-8.

11. Gopal V. BRITE study on school bullying in Dehradun. The Times of India. 2009;7-4.

12. Graham S, Juvonen J. Self-blame and peer victimization in middle school: an attributional analysis. Dev Psychol. 1998;34(3):587-538.

13. Olweus D. Schoolyard bullying - Grounds for intervention. School Safety, Fall. 1989;4-11.

14. Olweus D. Bully/victim problems among schoolchildren: Basic facts and effects of a school based intervention program. In: Pepler D, Rubin K (Eds.), The Development and Treatment of Childhood Aggression Hillsdale, Erlbaum. 1991.
15. Pepler DJ, Craig WM, Ziegler S, et al. An evaluation of an anti-bullying intervention in Toronto schools. Canadian Journal of Community Mental Health. 1994;13(2):95-110.

16. Omestoe FF. Correlates of bulling among secondary school students in Ibadan, North East Local Government Area of Oyo state. A published M.Ed Thesis of Obafemi Awolowo University, Ile-Ife, Nigeria. 2010.

17. Rigby K, Slee PT. Dimensions of interpersonal relation among Australian children and implications for psychological well-being. J SOC Psychol. 1993;133(1):33-42.

18. Cutner JD, Smith LF. Who am I? The role of self-concept confusion in understanding the behaviour of people with low self-esteem. In: Baumeister R (Eds.), Self Esteem: The Puzzle of low self-regard New York, Plenum Press, UK. 1999. p.3-20.

19. Winnicott CB. Psychoanalytic explorations. Columbia University Press, USA. 1978. p.1-602.

20. Rigby K. Psychosocial functioning in families of Australian adolescent schoolchildren involved in bully/victim problems. Journal of Family Therapy. 1994;16(2):173-187.

21. Baumeister A, Kampbell DM, Smith D. Bullying in schools: Selfreported anxiety, depression and self esteem in secondary school children. BMJ. 2008;17(7613):924-925.

22. Baumeister R. Evil: Inside Human Violence and Cruelty. Holt Paperbacks, UK. 2008. p.1-448.

23. Braithwaite J. Crime, Shame and Reintegration. Cambridge University Press, UK. 1989;1-216.

24. Dharamakumar M. School bullying in Indian schools. The Hindu. 2008;1-6.

25. Erickson EH. Understanding and preventing bullying. In: Tonry M (Ed.), Crime and justice. A review of research. The University of Chicago Press, England, UK. 1963.

26. Parada RH, Marsh HW, Yeung AS. Bullying in schools: Can self-concept theory shed any light? Paper presented at the AARE -NZARE Annual Conference, Melbourne Conference Centre, Victoria, Australia. 1999.

27. Parada RH. Adolescent Peer Relations Instrument: A theoretical and empirical basis for the measurement of participant roles in bullying and victimisation of adolescence: An interim test manual and a research monograph: A test manual. Bankstown: Publication Unit, Self-concept Enhancement and Learning Facilitation (SELF) Research Centre, University of Western Sydney, Australia. 2000.

28. Parada RH. Beyond bullying secondary schools program: Consultant's handbook. Sydney, Australia: Publications Unit, Self-Concept Enhancement and Learning Facilitation (SELF) Research Centre, University of Western Sydney, Australia. 2002.

29. Parada RH. School bullying: Psychosocial determinants and effective intervention. Unpublished doctoral dissertation, University of Western Sydney, Australia. 2005.

30. Parada RH, Marsh HW, Craven RG, et al. Bullying in schools: What can we glean from self-concept theory? Paper presented at the Australian Association for Research in Education Conference, Parramatta, Australia. 2005.

31. Parada RH, Marsh HW, Yeung AS. Bullying in schools: Can selfconcept theory shed any light? Paper presented at the Australian Association for Research in Education Conference, Melbourne, Australia. 1999.

32. Pelligrini AD, Bartini M. Dominance in early adolescent boys: Affiliative and aggressive dimensions and possible functions. MerrillPalmer Quarterly. 2001;47:142-163.

33. Pelligrini AD, Long JD. A sexual selection theory longitudinal analysis of sexual segregation and integration in early adolescence. Journal of ExperimentalChild Psychology. 2003; 85(3):257-278. 
34. Pepler DJ, Craig WM. About bullying - Understanding this underground activity. Orbit. 2000;25(3):32-34.

35. Price CB, Dodge T. Bullies move beyond the schoolyard. A preliminary look at cyberbullying. Youth Violence and Juvenile Justice. 1989;4(2):148-169.

36. Rican P. Family values may be responsible for bullying. Studia psychologica. 1995;37(1):31-36.

37. Rican P, Klicperova M, Koucka T. Families of bullies and their victims: A children's view. Studia Psychologica. 1993;35(3):261-266.

38. Rigby K. Bullying in schools-and what to do about it. Melbourne: ACER. Rigby K, Cox I (1996) The contribution of bullying at school and low self-esteem to acts of delinquency among Australian teenagers. Personality \& Individual Differences. 1996;21:609-612.

39. Rigby K. Countering bullying in schools. CAFHS Forum. 1993;1(2):19-21.

40. Rubin KH. Introduction (Special topic: Peer relationships and social skills in childhood - An international perspective.) Human Development . 1990;33:221-224.
41. Rubin K, Bream L, Rose-Krasnor L. Social problem solving and aggression in childhood. In: Pepler D, Rubin K (Eds.), The Development and treatment of childhood aggression. Hillsdale, New Jersey, USA. 1991. p.219-248.

42. Rubin KH, Coplan RJ. Peer relationships in childhood. In Bornstein MH, Lamb ME (Eds.), Developmental Psychology. An advanced text book ( $3^{\text {rd }}$ edn), Taylor \& Francis, UK. 1992. p.519-578.

43. Rubin I, Smith PK. Types of bullying behaviour and their correlates. Aggressive Behaviour. 1990;20(5):359-368.

44. Slee PT. Peer victimization and its relationship to depression among Australian primary school students. Personality and Individual Differences. 1992;18(1):57-62.

45. Slee PT. The P.E.A.C.E pack: A program for reducing bullying in our schools. Australian Journal of Guidance and Counseling. 1996;6:63-69. 